\title{
From the Editor
}

Business Economics (2011) 46, 131-132.

doi: $10.1057 /$ be. 2011.20

$\mathrm{T}$ his issue is devoted exclusively to papers that were presented at the NABE Economic Policy Conference on March 6-8, 2011 in Arlington, VA. Although Business Economics' practice is to publish a combination of papers that are presented at our conferences and submitted papers, this special issue is a departure because it is focused on the Economic Policy Conference alone, together with two book reviews. The reason for the departure is that a generous grant to the NABE Foundation was made by the Peter G. Peterson Foundation for the purpose of expanding the audience of the Economic Policy Conference, and the NABE Board of Directors decided that devoting a special issue of Business Economics to the Policy Conference was a good way to honor that intention.

The selection of the articles was made by me in consultation with members of the Editorial Board who were at the Conference. However, three qualifications are necessary. First, not all papers that we would have liked to publish became available. Second, we were not able to cover all of the sessions, so that it is likely that some papers that we would otherwise have liked to publish slipped between the cracks. Third, some excellent presentations were such that they did not lend themselves to development as journal papers because they were devoted to topics that were of such short-run or fast-moving concern that they would be out of date before they could be printed.

That said, this issue's first paper is Austan Goolsbee's view of the U.S. economy and the challenges before it from his perspective as Chairman of the Council of Economic Advisers. He emphasizes the difficulty of climbing out of a hole as deep as the one into which the U.S. economy was dropped and points out that much, but by no means all, of the current budget deficit problems will be alleviated significantly by a strong recovery.

Staying on the topic of fiscal policy, Douglas W. Elmendorf, the Director of the Congressional
Budget Office offers and discusses four observations on the state of the federal budget. It is a clear and stark picture of what most readers of Business Economics already know: there is no easy resolution to the U.S. federal budget situation. Although there is no shortage of feasible solutions, Elmendorf makes it clear that each would involve some combination of painful increases of revenue and cuts of expenditures, and they would also involve trade-offs concerning how quickly policy can be adjusted.

Robert Hormats, Under Secretary of State for Economic, Energy and Agricultural Affairs, explores six major political-economic phenomena that have emerged since World War II and how they are continuing to shape the global economy. These are the changing role of women in economics and politics, the global economic and financial system, the importance of state-supported enterprises, the impact of the Internet, the global diffusion of opportunity and innovation, and globalization as both an opportunity and a threat. How these forces continue to play out will have important consequences for the global economy.

Continuing with an international focus, C. Fred Bergsten of the Peterson Institute for International Economics explores what public policy goals are appropriate for U.S. improvement of its current account and what specific policies are necessary for the United States to once again become an "exporting juggernaut." $\mathrm{He}$ makes the case for easing U.S. export controls, aggressive pursuit of opening new markets, and forceful pursuit of realistic exchange rates. He also offers ideas on how these policies should be implemented.

One of the sessions at the Conference was on the economics of health care, namely, "Will the health care cost curve be bent?" Charles S. Roehrig of the Altarum Institute's Center for Studying Health Spending provides an overview of the unsustainable trends in health care spending and illuminates the distinction between bending the curve and shifting it. Many current proposals will do the latter, but solution to the long run problem requires the former.

The Patient Protection and Affordable Care Act of 2010 was bitterly contested and provides 
fodder for the 2012 election. One of its major goals was to "bend the trend" of health care costs. Gail R. Wilensky of Project HOPE, in a second paper from this session, finds that the bend-the-trend provisions of the Act are weak or are otherwise flawed. The collision of the irresistible force of health care costs that cannot be tolerated and the immovable object of entrenched interests opposed to change is still on the way.

Another session was on the prospects and implications of electric automobiles. Ellen HughesCromwick of Ford Motor Company discusses how her company is approaching the challenges of participating in the increasingly competitive global market for electric automotive vehicles. A key component of its strategy is to gain production efficiency by using common platforms for electric and nonelectric vehicles so that a Ford Fusion, say, is available with either a conventional engine or a hybrid engine. Another is to develop the electrification infrastructure to make battery recharge convenient and inexpensive.

The session made clear that the main objectives of automotive vehicle electrification are improved environmental quality and energy security. Nayantara D. Hensel of the U.S. Navy, however, provides the economist's classic, "On the other hand, ...." This particular other hand concerns the dependence of electric vehicles and many other technologies on "rare earths"- little-known chemical elements that are critical inputs. They are called rare for a reason, and at present China controls 95 percent of the supply. Hensel's paper delineates how the developed world might be trading one kind of energy insecurity for another and how it is coping with this issue.

Because of the large number of papers from the Economic Policy Conference, this issue does not have Focus on Statistics, Focus on Industries and Markets, or Economics at Work features. It does, however, have two book reviews. The first book reviewed is Edward Glaeser's Triumph of the City: How Our Greatest Invention Makes Us Richer, Smarter, Greener, Healthier and Happier. In his review, John C. Goodman says that Glaeser has written "an ode to the city." The book debunks a number of popular myths and delineates the reasons that cities are such important contributors to welfare. The book also attacks a number of public policies that control or redirect the growth of cities, finding them to be counterproductive. Goodman finds that the book is well-written and entertaining, as well as presenting important facts and sound economic analysis.

The second book is Adapt: Why Success Always Starts with Failure by Tim Harford. Gerald L. Musgrave reviews it. The principal theme of the book is that failure is to be expected: the trick is how to cope with it. Well written for a lay as well as sophisticated audience, Harford's analysis applies to organizations and individuals. It has a general concern rather than a specifically economics focus and is not written from a particular ideological standpoint. Written from a British perspective, it provides interesting insights on economic phenomena as diverse as microfinance and the 2008 financial meltdown. Musgrave finds that, "It would be no mistake for business economists to read this book - and adapt accordingly." 